\title{
PENGARUH MODEL PEMBELAJARAN KOOPERATIF TIPE \\ THINK PAIR SHARE TERHADAP HASIL BELAJAR KIMIA \\ SISWA KELAS X MA QAMARUL HUDA BAGU TAHUN \\ PELAJARAN 2019/2020
}

\author{
Doni Setiawan', Hadi Kusuma Ningrat', Raehanah' \\ Tadris Kimia, FTK UIN Mataram, Mataram. Email: \\ doni.tapon99@gmail.com
}

\section{ABSTRAK}

Tujuan penelitian ini adalah untuk mengetahui pengaruh model pembelajaran kooperatif tipe think pair share (TPS) terhadap hasil belajar. Jenis penelitian ini adalah penelitian kuantitatif menggunakan pendekatan quasi eksperimen dan dilaksanakan dari bulan Februari sampai dengan Maret 2020. Populasi penelitian ini adalah semua kelas X MIPA MA Qomarul Huda Bagu Tahun Pelajaran 2019/2020. Sampel diperoleh dengan teknik sampling total (jenuh). Kelas A dijadikan sebagai kelas eksperimen yang diajarkan menggunakan model pembelajaran kooperatif tipe TPS, sedangkan kelas B dijadikan sebagai kelas kontrol yang diajarkan menggunakan model pembelajaran konvensional. Desain penelitian yang digunakan adalah posttest-only control group design. Metode pengumpulan data yang digunakan adalah tes tertulis dalam bentuk pilihan ganda. Data dalam penelitian ini tidak normal sehingga uji hipotesis menggunakan uji Man Whitney Test. Dari hasil analisis data diperoleh bahwa nilai Asymp sig sebesar 0,011 < 0,05 maka dapat disimpulkan bahwa Ha diterima artinya Ada pengaruh model pembelajaran kooperatif tipe TPS terhadap hasil belajar kimia siswa kelas X MA Qomarul Huda Bagu Tahun Pelajaran 2019/2020.

Kata Kunci: Hasil Belajar, Model Pembelajaran Think Pair Share (TPS), Reaksi Oksidasi dan Reduksi. 
Doi:

\section{PENDAHULUAN}

Kurikulum pada era sekarang ini memegang peranan penting dalam pendidikan, sebab pada dasarnya kurikulum berfungsi sebagai pedoman dalam meningkatkan kualitas pendidikan. Pelaksanan kurikulum merupakan sesuatu yang baru bagi guru, dalam hal ini guru dituntut untuk berfikir kreatif dalam melaksanakan kegiatan belajar mengajar atau dengan kata lain mengaplikasikan ilmunya kepada peserta didik dalam proses belajar mengajar. Karena guru adalah orang yang langsung berhadapan dengan siswa, hasil belajar sangat ditentukan oleh guru itu sendiri. Jadi, dalam pelaksanaan pembelajaran guru harus menyiapkan model pembelajaran yang akan digunakan nantinya untuk mendorong siswa lebih aktif dari pada guru sesuai tuntutan dalam kurikulum 2013 yang berkembang saat ini (Dina, dkk., 2015).

Model pembelajaran adalah suatu perencanaan atau pola yang digunakan sebagai pedoman atau dengan kata lain sebagai langkah pembelajaran dan perangkatnya untuk mencapai tujuan pembelajaran di dalam kelas. Model pembelajaran mengacu pada pendekatan pembelajaran yang akan digunakan, termasuk di dalamnya tujuan-tujuan pengajaran, tahap-tahap dalam kegiatan pembelajaran dan pengolahan kelas (Afandi, dkk., 2013). Sedangkan menurut Suprijono (2010) bahwa model pembelajaran dapat dikatakan sebagai kerangka berfikir yang sistematis dalam mengorganisasikan pengalaman belajar untuk mencapai tujuan belajar.

Berdasarkan beberapa kutipan di atas maka dapat disimpulkan bahwa model pembelajaran adalah bentuk pembelajaran yang tergambar dari awal sampai akhir yang diaplikasikan oleh guru dalam proses pembelajaran berlangsung. Jadi, adanya model pembelajaran dapat menjadi pedoman bagi para perancang dan guru dalam merencanakan aktivitas belajar mengajar, sehingga dengan demikian tercipta situasi belajar yang efektif dan efisien sesuai dengan pokok bahasan pada mata pelajaran sains. 
Sains yang sering dikenal dengan Ilmu Pengetahuan Alam (IPA) didefinisikan sebagai pengetahuan yang diperoleh melalui pengumpulan data dengan eksperimen, pengamatan, dan dedukasi untuk menghasilkan suatu penjelasan tentang sebuah gejala yang dapat dipercaya (Putri, dkk., 2017). Salah satu cabang mata pelajaran sains (IPA) adalah kimia. Kimia merupakan salah satu cabang ilmu pengetahuan alam yang penting, yang berguna untuk mengetahui apa yang terjadi di lingkungan sekitar dan sering dianggap sebagai mata pelajaran yang sulit dipahami oleh siswa. Kimia dianggap sebagai ilmu yang kurang menarik dan sulit oleh siswa karena kimia erat hubungannya dengan ide-ide atau konsep abstrak dan kata-kata khusus. Untuk itu perlu digunakan modelmodel pembelajaran yang sesuai untuk digunakan supaya tercipta situasi belajar yang efektif (Ibrahim, 2010).

Berdasarkan hasil observasi di Madrasah Aliyah Qamarul Huda Bagu, ternyata MA Qamarul Huda Bagu merupakan salah satu sekolah yang menggunakan kurikulum 2013. Kurikulum 2013 menekankan pada pembelajaran yang berpusat pada siswa. Akan tetapi, saat kegiatan pembelajaran kimia berlangsung metode ceramah masih sering digunakan oleh guru. Hal ini berarti pembelajaran masih berpusat pada guru. Diskusi hanya dilakukan dengan teman sebangku dan itu dilakukan pada saat guru memberikan latihan soal saja, guru di sini tidak pernah menekankan siswa untuk berkerja sama atau berkelompok untuk bertukaran pendapat, saling membantu dan sharing pada siswa lain. Hal tersebut menyebabkan siswa cenderung pasif dalam kelas. Guru hanya menyampaikan kimia sebagai produk dan siswa menghafal produk yang diberikan oleh guru. Jadi di sini guru cenderung memberikan materi yang sudah ada atau tertulis dan memberikan contoh soal tanpa menyuruh siswa menemukan konsep-konsep tersendiri. Dalam artian guru hanya menjelaskan apa yang sudah ada di buku dan menghafal yang sudah ada. Hal tersebut mengakibatkan tingkat pemahaman dan hasil belajar siswa belum optimal (Arbain, observasi 2019) 
Doi:

Beberapa permasalahan yang terjadi di MA Qamarul Huda Bagu berdasarkan hasil wawancara guru kimia kelas $X$ antara lain: (1) guru masih menggunakan metode konvensional (ceramah) dalam kegiatan pembelajaran; (2) masih terdapat siswa-siswi yang memiliki hasil belajar di bawah Kriteria Ketuntasan Minimal (KKM) di Kelas X Semester Genap; dan (3) siswa-siswi juga banyak mengalami kesulitan dalam memahami konsep-konsep materi kimia (Arbain, wawancara 2019). Hal ini tampak dari nilai rata-rata ulangan harian dan nilai rata-rata hasil ulangan tengah semester pelajaran kimia kelas $\mathrm{X}$ yang belum memenuhi standar KKM. Kriteria Ketuntasan Minimal (KKM) yang telah ditetapkan oleh sekolah yaitu 75. Hasil ulangan harian pertama siswa yaitu sebanyak 54\% dari 44 siswa mendapatkan nilai di atas KKM. Pada ulangan harian kedua sebanyak $61 \%$ dari 44 siswa mendapatkan nilai di atas KKM. Pada MID semester 68\% dari 44 siswa mendapatkan nilai di atas KKM (Arbain, wawancara 2019)

Melihat hasil belajar siswa di atas menandakan bahwa proses pembelajaran di MA Qamarul Huda Bagu masih tergolong belum optimal. Untuk itu diperlukan suatu pembelajaran yang efektif, sehingga dapat mempengaruhi hasil belajar siswa. Dalam proses belajar mengajar terdapat banyak model pembelajaran, salah satunya adalah model pembelajaran kooperatif. Pembelajaran kooperatif merupakan struktur kegiatan belajar mengajar berkelompok. Pembelajaran kooperatif sendiri memiliki banyak tipe salah satunya adalah think pair share (TPS). Menurut Suhardi (2018) model kooperatif tipe TPS adalah salah satu model pembelajaran kooperatif yang merupakan struktur kegiatan belajar mengajar berkelompok yang dapat mendorong partisipasi siswa dalam kelas dan saling menghargai satu sama lain. Sedangkan menurut Trianto (2007) TPS merupakan jenis pembelajaran kooperatif yang dirancang untuk mempengaruhi pola interaksi siswa. Model think pair share ini berkembang dari penelitian belajar kooperatif dan waktu tunggu.

Adapun langkah-langkah pembelajaran TPS adalah thinking (berpikir), pairing (berpasangan), dan sharing (berbagi). Pada 
tahap atau langkah pertama thinking (berpikir) guru mengajukan pertanyaan seputar materi pembelajaran, kemudian siswa diminta untuk memikirkan pertanyaan tersebut secara mandiri dan diberikan waktu beberapa menit. Tahap kedua pairing (berpasangan), guru meminta siswa berpasangan dengan siswa yang lain untuk mendiskusikan apa yang telah dipikirkannya pada tahap pertama. Selanjutnya sharing (berbagi) guru meminta kelompok pasangannya untuk berbagi hasil diskusi keseluruh kelas tentang apa yang mereka telah diskusikan (Rosita dan Leonard, 2013)

Salah satu kelebihan dari model ini adalah lebih mengoptimalkan keaktifan siswa, dapat bekerja sendiri-sendiri terdahulu, ini dapat membuat siswa percaya diri dan mendapat kesempatan untuk berkerja sama dengan teman diskusi, dan ini juga akan membuat hubungan antar siswa semakin baik. Disamping itu juga langkah-langkah yang digunakan dalam model TPS ini menarik yaitu memberi waktu lebih banyak pada siswa. Karakteristik dari model ini juga menarik yaitu melibatkan pada semua siswa untuk kepemimpinan bersama, karena dalam kelompok berhak untuk berbicara dan berpendapat, menekankan peranan anggota, menekankan interaksi dan saling menghargai satu sama lain (Fajaryanti, dkk., 2014).

Beberapa penelitian telah berhasil dengan menggunakan model pembelajaran ini dalam kelas, salah satunya adalah penelitian di SMAN 1 Bireuen yang dilakukan oleh Marlina, dkk (2014) hasil penelitinnya menyimpulkan bahwa penggunaan model ini memberikan peningkatan kemampuan berkomunikasi siswa serta berkerja sama siswa, sehingga hasil belajar siswa dapat meningkat. Hal ini sejalan dengan hasil penelitian Hermawati (2010) dan Kasimuddin (2015) yang menunjukkan model pembelajaran kooperatif tipe TPS berpengaruh positif terhadap hasil belajar siswa.

\section{METODE PENELITIAN}


Doi:

Penelitian ini adalah penelitian kuantitatif. Pendekatan penelitian yang digunakan adalah pendekatan quasi eksperimen. Penelitian ini dilakukan pada bulan Februari-Maret 2020 dengan jumlah populasi sekaligus sampel sebanyak 33 orang. Kelas eksperimen terdiri dari 18 siswa dan kelas kontrol terdiri dari 15 siswa. Desain penelitian menggunakan metode posstest-only control group design. Instrumen penelitian ini adalah test evaluasi berupa pilihan ganda. Uji Prasarat analisis menggunakan uji normalitas. Uji hipotesis dalam penelitian ini adalah uji MannWhitney Test. Analisis data menggunakan aplikasi SPSS versi 16 .

\section{HASIL DAN PEMBAHASAN}

\section{Hasil Penelitian}

\section{Data Hasil Belajar}

Data yang diperoleh dari penelitian ini berupa hasil belajar. Data diperoleh melalui tes evaluasi yang dilakukan setelah proses pembelajaran selesai. Adapun deskripsi singkat hasil belajar yang diperoleh yaitu nilai maksimum pada kelas eksperimen dan kontrol yaitu 92 dan nilai minimum 69. Adapun jumlah nilai rata-rata pada kelas eksperimen 83,44 dan kelas kontrol yaitu 77,46 .

\begin{tabular}{lcc}
\multicolumn{2}{c}{ Tabel 1. Deskripsi Nilai Hasil Belajar Kimia } \\
\hline \multicolumn{1}{c}{ Keterangan } & $\begin{array}{c}\text { Kelas } \\
\text { Eksperimen }\end{array}$ & $\begin{array}{c}\text { Kelas } \\
\text { Kontrol }\end{array}$ \\
\hline Jumlah sampel & 18 & 15 \\
Nilai maksimum & 92 & 92 \\
Nilai minimum & 69 & 69 \\
Standar KKM & 75 & 75 \\
Siswa di atas KKM & 17 & 12 \\
Siswa di bawah KKM & 1 & 3 \\
Nilai rata-rata & 83,44 & 77,46 \\
Standar deviasi & 6,54 & 6,22 \\
\hline
\end{tabular}




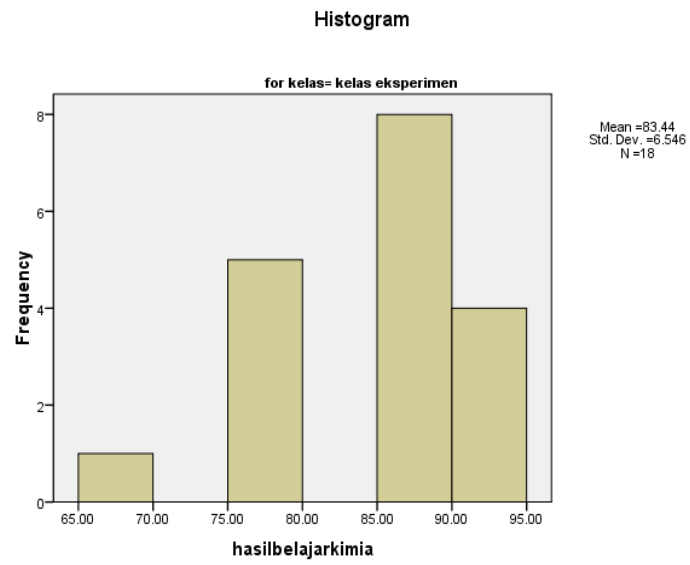

Gambar 1. Grafik Distribusi Frekuensi Hasil Belajar Eksperimen

Histogram

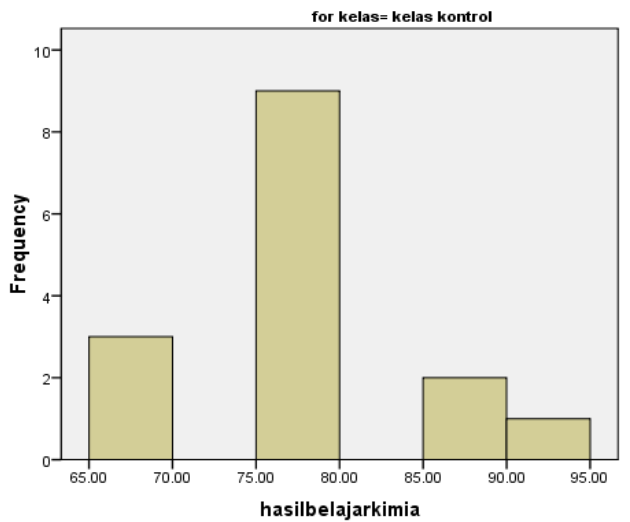

Mean $=77.47$
Std. Dev. $=6.221$
$N=15$

Gambar 2. Grafik Distibusi Frekuensi Hasil Belajar Kelas Kontrol

Grafik distribusi frekuensi di kelas eksperimen menunjukkan condong ke kanan. Hal ini menunjukkan siswa lebih banyak mendapatkan nilai di atas rata-rata kelas. Sebaliknya pada grafik distribusi frekuensi kelas kontrol condong ke kiri. Hal ini menunjukkan siswa lebih banyak mendapatkan nilai di bawah rata-rata kelas. Kecondongan data 
pada salah satu arah ini juga menandakan distribusi data yang tidak normal.

\section{Uji Prasyarat}

Hasil uji normalitas dengan menggunakan program SPSS dapat di lihat pada tabel 2:

Tabel 2. Output Hasil Uji Normalitas

\begin{tabular}{|c|c|c|c|c|c|c|c|}
\hline \multicolumn{8}{|c|}{ Tests of Normality } \\
\hline & \multirow{2}{*}{ kelas } & \multicolumn{3}{|c|}{ Kolmogorov-Smirnov ${ }^{\mathrm{a}}$} & \multicolumn{3}{|c|}{ Shapiro-Wilk } \\
\hline & & Statistic & Df & Sig. & Statistic & Df & Sig. \\
\hline \multirow[t]{2}{*}{ Hasilbelajarkimia } & $A$ & .261 & 18 & .002 & .872 & 18 & .020 \\
\hline & $B$ & .330 & 15 & .000 & .824 & 15 & .007 \\
\hline \multicolumn{8}{|c|}{ a. Lilliefors Significance Correction } \\
\hline
\end{tabular}

Berdasarkan tabel di atas terlihat bahwa nilai sig hasil belajar kelas eksperimen 0,020 $<0,05$ artinya data tidak berdistribusi normal. Begitu juga dengan kelas kontrol diperoleh nilai sig 0,007 $<0,05$ menunjukkan bahwa data tidak berdistribusi normal. Karena data tidak berdistribusi normal maka uji hipotesis yang selanjutnya dilakukan adalah uji nonparametris yaitu Man-Whitney test.

\section{Uji Hipotesis}

Berikut hasil uji hipotesis Man-Whitney menggunakan program SPS dapat dilihat pada tabel 3 di bawah ini.

\section{Tebel 3. Hasil Uji Hipotesis Man Whitney}

\begin{tabular}{ll}
\hline \multicolumn{2}{c}{ Test statistics $^{\mathbf{b}}$} \\
\hline & Hasil belajar kimia \\
\cline { 2 - 2 } Mann-Whitney U & 69.000 \\
Wilcoxon W & 189.000 \\
Z & -2.527 \\
Asymp. Sig. (2-tailed) & .011 \\
Exact Sig. [2*(1-tailed Sig.)] & $.016^{\mathrm{a}}$ \\
\hline a. Not corrected for ties. \\
\hline b. Grouping Variable: kelas \\
\hline
\end{tabular}


Berdasarkan output dari uji Man-Whitney diketahui bahwa nilai Asymp sig sebesar 0,011<0,05, maka Ha diterima. Artinya ada pengaruh model pembelajaran kooperatif tipe TPS terhadap hasil belajar kimia siswa kelas X MA Qomarul Huda Bagu Tahun Pelajaran 2019/2020.

\section{PEMBAHASAN}

Penelitian ini bertujuan untuk mengetahui pengaruh penerapan model pembelajaran kooperatif tipe TPS terhadap hasil belajar siswa kelas X MA Qomarul Huda Bagu Tahun Pelajaran 2019/2020. Berdasarkan hasil pengujian hipotesis menghasilkan nilai Asymp sig 0,011<dari 0,05 sehinga dapat disimpulkan bahwa ada pengaruh model pembelajaran TPS terhadap hasil belajar siswa MA Qamarul Huda Bagu. Hasil belajar siswa yang menggunakan model pembelajaran TPS lebih baik dibandingkan dengan hasil belajar siswa yang menggunakan model pembelajaran langsung (konvensional). Hal ini juga bisa dilihat dari perbedaan nilai ratarata hasil belajarnya. Kelas eksperimen memiliki nilai rata-rata 83,44 sedangkan kelas kontrol memiliki nilai rata-rata 77,46.

Seorang pendidik dituntut untuk menciptakan suasana belajar yang efektif dalam proses kegiatan belajar mengajar dan melibatkan siswa lebih aktif daripada guru. Diharapkan dengan terciptanya suasana belajar yang efektif dapat mempengaruhi hasil belajar siswa. Salah satu cara menciptakan suasana belajar yang efektif yaitu dengan cara menerapkan model pembelajaran. Salah satu model pembelajaran yang menciptakan suasana belajar yang efektif adalah model pembelajaran kooperatif tipe TPS. Hal ini sesuai dengan pendapat Surayya, dkk (2014) yang menjelaskan bahwa model pembelajaran kooperatif tipe TPS merupakan model pembelajaran efektif yang membuat variasi suasana pola diskusi dan melibatkan siswa secara aktif, dapat berkerja sendiri terdahulu dan mendapat kesempatan untuk berkerja sama dengan teman diskusinya. Prosedur yang digunakan dalam model TPS dapat memberi siswa lebih banyak waktu berpikir, merespon dan saling 
Doi:

membantu. Hal ini sejalan dengan yang diungkapkan oleh Hartini, dkk (2016) bahwa model pembelajaran kooperatif tipe TPS dirancang agar siswa terlatih berkomunikasi untuk mengungkapkan berbagai ide yang ada di pikirannya selama proses pembelajaran, baik kepada guru maupun temannya. Hal ini dapat dilihat dari tahap-tahap pembelajaran TPS yaitu berpikir, berpasangan, dan berbagi. Pada tahap berpasangan dan berbagi kemampuan berkomunikasi sangat diperlukan untuk menyampaikan ide-ide kepada orang lain agar dapat dipahami.

Pada kelas kontrol yang menggunakan model pembelajaran konvensional guru menjelaskan materi menggunakan metode ceramah. Metode ceramah sendiri membuat siswa kurang aktif dalam kelas, terlihat sekali guru lebih mendominasi selama proses pembelajaran berlangsung, sebagian siswa kurang memperhatikan guru saat menjelaskan sehingga siswa mudah jenuh dalam proses kegiatan belajar mengajar dan siswa cepat merasa bosan karena cenderung lebih banyak waktu luang pada guru daripada siswa yang hanya mendengar dan menangkap sekilas materi saja. Pengalaman berkerja sendiri dan berdiskusi dengan teman kurang didapatkan dalam proses pembelajaran dengan menggunakan metode ceramah ini. Jadinya siswa kurang percaya diri dalam proses pembelajaran. Hal ini sejalan dengan yang diungkapkan oleh Ruseffendi (2006) dalam metode konvensional, guru merupakan gudang ilmu, guru bertindak otoriter, guru mendominasi kelas. Djamarah dan Zain (2013) juga menyatakan beberapa kelemahan metode ceramah yaitu: a) mudah menjadi verbalisme (pengertian kata-kata); b) visual menjadi rugi, sementara auditif besar menerima manfaatnya; c) bila selalu digunakan dan terlalu lama, akan membosankan; d) guru menyimpulkan bahwa siswa mengerti dan tertarik pada ceramahnya; e) menyebabkan siswa menjadi pasif.

Metode ceramah tentunya tidak akan menimbulkan timbal balik yang baik antara guru dengan siswa maupun siswa dengan siswa yang lain, karena pada dasarnya pelaksanaan pembelajaran pada kelas kontrol hanya berpatokan pada guru saja. Hal tersebut mengakibatkan siswa kurang memahami pelajaran yang 
disampaikan sehingga berdampak terhadap hasil belajar siswa yang kurang optimal. Hal ini sesuai dengan hasil penelitian dari Kusuma dan Aisyah (2012) yaitu terjadi peningkatan aktivitas belajar dan pola diskusi bila dibandingkan dengan aktivitas belajar awal sebelum implementasi model pembelajaran kooperatif tipe TPS. Pada pembelajaran sebelumnya, yakni pembelajaran dengan metode ceramah, baru $24,58 \%$ siswa di kelas yang aktif. Setelah dilakukan implementasi model pembelajaran kooperatif tipe TPS aktivitas belajar siswa dalam kelas meningkat sebesar $36,70 \%$ menjadi $61,28 \%$.

Sementara itu hasil belajar siswa lebih tinggi pada kelas eksperimen disebabkan karena dalam proses pembelajaran siswa berperan aktif, memiliki jiwa berkerja sama dan memiliki rasa percaya diri yang tinggi dalam setiap materi yang diajarkan. Prosedur yang digunakan dalam model TPS dapat memberi siswa lebih banyak waktu berpikir, merespon dan saling membantu. Hal ini sesuai dengan literatur yang menyatakan bahwa TPS adalah salah satu model pembelajaran yang cukup efektif untuk meningkatkan keaktifan siswa dalam proses belajar mengajar, dan siswa dituntut untuk melakukan aktivitas yang lebih banyak saat pembelajaran berlangsung. TPS sendiri memberikan kesempatan kepada siswa untuk berkerja sendiri terlebih dahulu serta berkerja sama dengan teman lainnya atau teman diskusinya (Febrian dan Aisyah, 2012).

Pembelajaran TPS juga mengajarkan siswa untuk saling menghargai satu sama lain dan mendorong komunikasi antar siswa sehingga hubungan antar siswa semakin baik. Keaktifan siswa dalam proses pembelajaran juga dapat membuat pola interaksi yang baik antara guru dengan siswa dan juga siswa dengan siswa sehingga pembelajaran tidak lagi berpusat pada guru dan dapat membuat siswa tetap bersemangat dalam melakukan pembelajaran. Hal ini dapat meningkatkan pemahaman siswa terhadap materi yang diajarkan, sehingga dapat berpengaruh positif terhadap hasil belajar siswa. 
Doi:

Hasil penelitian ini sesuai dengan penelitian yang telah dilakukan oleh Kasimuddin (2015) menyimpulkan bahwa terdapat pengaruh positif pembelajaran kooperatif tipe TPS terhadap hasil belajar fisika. Selain itu, Marlina dkk (2014) menjelaskan bahwa penggunaan model TPS ini memberikan peningkatan kemampuan berkomunikasi siswa serta berkerja sama siswa sehingga hasil belajar siswa dapat meningkat.

Disamping meningkatkan hasil belajar dengan menggunakan model pembelajaran kooperatif tipe TPS, peneliti juga mendapatkan kendala-kendala dalam menggunakan model tersebut. Adapun kendala-kendala pelaksanaan pada kelas eksperimen, yaitu waktu yang dibutuhkan untuk pembelajaran mengunakan model TPS cukup lama dan guru kewalahan dalam mengontrol jalannya diskusi dikarenakan baru menggunakan model TPS. Hal ini sesuai dengan pendapat Hermati (2010) yang menyatakan bahwa dalam model pembelajaran TPS sulit mengubah kebiasaan siswa belajar dari yang dengan cara mendengarkan ceramah diganti dengan belajar menggunakan model TPS.

\section{KESIMPULAN}

Berdasarkan hasil penelitian dan pembahasan, maka dapat disimpulkan bahwa hasil belajar kimia siswa yang menggunakan model pembelajaran TPS lebih baik dibandingkan dengan hasil belajar siswa yang menggunakan model pembelajaran langsung (konvensional). Oleh karena itu ada pengaruh model pembelajaran TPS terhadap hasil belajar kimia siswa MA Qamarul Huda Bagu Tahun Pelajaran 2019/2020.

\section{DAFTAR PUSTAKA}

Afandi, M., Chamalah, E., \& Wardani, O. P. (2013). Model dan Metode Pembelajaran di Sekolah. Semarang: Unissula Press. Arbain. 2019 Kegiatan Obeservasi dan Wawancara. MA Qamarul Huda Bagu, Pringgarata, Loteng-NTB. 
Dina, A., Mawarsari., V. D., \& Suprapto, R. (2015). Implementasi Kurikulum 2013 Pada Perangkat Pembelajaran Model Discovery Learning Pendekatan Scientific Terhadap Kemampuan Komunikasi Matematis Materi Geometri SMK. JKPM. 2(1). 22-31.

Djamarah, S. B. \& Zain, A. (2013). Strategi Belajar Mengajar. Jakarta: Rineka Cipta.

Fajaryanti, D. E., Tiwow, V. M. A., \& Rahman, N. (2014). Penggunaan Model Pembelajaran Kooperatif Tipe Think Pair Share (TPS) Pada Pokok Bahasan Struktur Atom Untuk Meningkatka Hasil Belajar Siswa Kelas X SMA Negeri 2 Palu. Jurnal Akademika Kimis. 3(3). 129-134.

Hartini., Maharani, Z. Z., \& Rahman, B. (2016). Penerapan Model

Pembelajaran Think-Pair-Share untuk Meningkatkan

Kemampuan Komunikasi Matematis Siswa SMP. KREANO: Jurnal Matematika Kreatif-Inovatif. 7(2). 131-135.

Hermati, L. (2010). Pengaruh Model Pembelajaran Kooperatif Tipe Think Pair Share (TPS) Terhadap Hasil Belajar Siswa Pada Konsep Sistem Reproduksi Manusia. Skripsi, FITK UIN Syarif Hidayatullah Jakarta.

Ibrahim, A. R. (2010). Upaya Meningkatkan Hasil Belajar Mahasiswa Melalui Penerapan Model Pembelajaran Think Pair and Share pada Mata Kuliah Kimia Dasar 1. Forum MIPA. 13(2). 77-81.

Kasimuddin. (2015). Penggunaan Model Pembelajaran Kooperatif Tipe Think Pair Share (TPS) Untuk Meningkatkan Aktivitas Dan Hasil Belajar Fisika Peserta Didik Kelas XI IPA 2 SMA Negeri 9 Makassar. Jurnal Pendidikan Fisika. 4(1). 54-72

Kusuma, F. W. \& Aisyah, M. N. (2012). Implementasi Model Pembelajaran Kooperatif Tipe Think Pair Share (TPS) Untuk Meningkatkan Aktivitas Belajar Akuntansi Siswa Kelas XI IPS 1 SMA Negeri 2 Wonosari Tahun Ajaran 2011/2012. Jurnal Pendidikan Akuntansi Indonesia. 10(2). 43-63.

Marlina., Hajidin., \& Ikhsan, M. (2014). Penggunaan Model Pembelajaran Kooperatif Tipe Think Pair Share (TPS) untuk 
Doi:

Meningkatkan Kemampuan Komunikasi dan Disposisi Matematis Siswa di SMA Negeri 1 Bireuen. Jurnal Didaktik Matematika. 1(1). 83-95.

Putri, I. S., Juliani, R., \& Lestari, I. N. (2017). Pengaruh Model Pembelajaran Discovery Learning Terhadap Hasil Belajar dan Aktivitas Siswa. Jurnal Pendidikan Fisika. 6(2). 91-94.

Rosita, I. \& Leonard. (2013). Meningkatkan Kerja Sama Siswa Melalui Pembelajaran Kooperatif Tipe Think Pair Share. FORMATIF: Jurnal Ilmiah Pendidikan MIPA. 3(1). 1-10.

Ruseffendi, E.T. (2006). Pengantar kepada Membantu Guru Mengembangkan Kompetensinya dalam Pengajaran Matematika untuk Meningkatkan CBSA. Bandung: Tarsito.

Suhardi, Y. (2018). Penerapan Model Pembelajaran Kooperatif Tipe TPS (Think Pair Share) untuk Meningkatkan Hasil Belajar Peserta Didik Pada Mata Pelajaran Kimia Tentang Termokimia di Kelas XI Mipa 2 SMA Negeri 7 Kota Bogor. Educate Jurnal Teknologi Pendidikan. 3(1). 53-74.

Suprijono, A. (2010). Cooperatif learning Teori \& Aplikasi PAIKEM. Yogyakarta: Pustaka Pelajar.

Surayya, L., Subagia, I. W., \& Tika, I. N. (2014). Pengaruh Model Pembelajaran Think Pair Share (TPS) Terhadap Hasil Belajar IPA Ditinjau Dari Keterampilan Berpikir Kritis Siswa. e-Jurnal Program Pascasarjana Universitas Pendidikan Ganesha Program Studi IPA. 4(1). 1-11.

Trianto. (2007). Model-model Pembelajaran Inovatif Berorientasi Konstruktivistik. Surabaya: Prestasi Pustaka. 